\title{
研究ハイライト(第 12回)
}

\section{動画付き研究速報}

\section{L字型表示面を用いた錯視 による裸眼立体映像生成}

\section{井阪＼cjkstart建氏，藤代一成氏}

Vol. 70, No. 6, pp. J142 J145（2016）

近年 VRやARが大きな盛り上がりを見せており，ドーム型で没入感を出すようなシステムや眼 鏡型のデバイスなどさまざまな形で出回っている．しかし，本論文でも指摘されているように，没 入感を得るためのドーム型のような大掛かりなシステムになったり，逆に眼鏡型のように人が身に

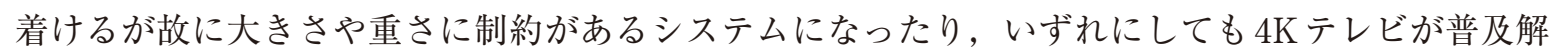
像度になりつつあるなかで，同等の映像クオリティを求めようとすると，費用対効果がトレードオ フの関係となってしまう。 そこで本論文では, 古くから 3Dトリックアートとして使われているア ナモルフォーシスとよばれる手法を用いて，効果的な裸眼立体表示機能を有する個人向け環境を， 2枚のデイスプレイを壁と床のようにL字型に組み合わせて手軽に構築できる手法を提案している.

基本的なコンテンツは，ある物体が光路を遮って壁や床などの他の物体に落とす影 (キャスト シャドウ）の効果により相対的な位置を調整し，off-axis 法による投影で 2 枚のディスプレイに描画 する絵を生成している．またウェブカメラで観察しているユーザ側を撮影し，Viola-Jones 法を用い てユーザの顔追跡を行い，バーチャルカメラの3次元位置をリアルタイムに制御することで，ユー ザの観察位置に依らず違和感のない立体映像を提供している．本論文ではまずユーザの視線の挙動 を確認し，その上で定性的な評価実験を行った。その結果，提案手法によるシーンに含まれる壁と 床の構図およびキャストシャドウが，表示対象に対するユーザの立体感の向上に寄与していること がわかった。さらに立体映像をより際立たせるために拡張仮想感の概念を取り入れて，ディスプレ イを 1 枚追加したシステムの構築や，周辺環境の映り込みの擬似再現，さらに単眼で観察すると立 体感が増強される特徵を利用してシステム前方にあえて遮蔽物を配置する手法などが提案，実装さ れている。これらはいずれも動画として電子付録に掲載されており，単眼ゆえにいかに立体感が強 調されているかがよくわかる映像となっている.

本論文で提案されているシステムは，L字型の構造が多く含まれる人工物に埋め込みやすい形状 であり，古くから使われている3Dトリックアートという技術を現代社会の中で活かすことを見据 えた実用的な研究であることから，今後より効果的な社会実装が期待される.

市橋保之 (情通機構) 


\title{
L 字型表示面を用いた錯視による裸眼立体映像生成
}

\author{
Naked-Eye 3D Imaging through Optical Illusion \\ using L-Shaped Display Surfaces
}

井阪 建 ${ }^{\dagger}$, 正会員 藤 代一 成

Takeru Isaka $^{\dagger}$ and Issei Fujishiro ${ }^{\dagger}$

\begin{abstract}
あらまし 安価ながら効果的な裸眼立体表示を可能にするディスプレイシステムの開発は, ビジュアルコンピューティ ング分野におけるきわめて重要な課題の一つである。ホログラフィに代表されるような，ハードウェアの描像原理を高度 化することで発展してきた既存システムは，現時点では生成映像の品質を向上させにくいという課題がある．そこで本論 文では，複数枚の汎用ディスプレイを直交に配置した L 字型の表示空間上で，陰影と運動視差を中心とする単眼性の奥行 き知覚要因を利用して，一般的な $2 \mathrm{D}$ グラフィックスと同等の解像度と明度をもつ，個人向けの裸眼立体映像を手軽に生 成する手法を提案する．ユーザの視線追跡により本手法の有效性を確認する予備的評価についても報告する.
\end{abstract}

キーワード：裸眼立体視，アナモルフォーシス，マルチディスプレイ，顔追跡，運動視差

\section{1. ま え がき}

立体ディスプレイは，両眼視差や輻輳角の変化など，ヒト が立体物を知覚する際の要因を利用することで, 表示刘象 そのものの姿形を, 高臨場感を伴って直接ユーザに伝える ことができる. その際, 装着デバイスを必要としなければ, ユーザは自然な状態で対象を知覚することができる，その 目的で 2 眼式や空中像表示方式など, さまざまな描像原理 の表示系が提案されてきた。

しかし, 既存システムは, 費用刘効果がトレードオフの 関係になる傾向があり, 表現できる映像自体の解像度や輝 度といった品質面で, 普及解像度が $4 \mathrm{~K}$ に迫ろうとする スタディスプレイと同等のレベルには達していない.ユー ザの奥行き知覚を摇さぶっても, 映像の品質を犠牲にして しまってはユーザを興ざめさせてしまう。そこで本研究で は，近年注目されている $3 \mathrm{D}$ トリックアートの錯視効果に 着目し, 対象コンテンツの描画方法と表示ハードウェアの 簡易的な拡張を組み合わせることによって，簡便ながら高 品質な個人向け裸眼立体映像生成手法を提案する.

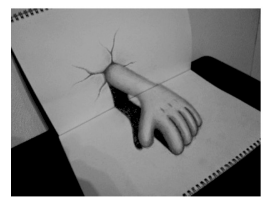

図 1 永井秀幸氏による作品例

2016 年 1 月 29 日受付, 2016 年 5 月 13 日採録 †慶應義塾大学 大学院 理工学研究科

（市 223-8522 横浜市港北区日吉 3-14-1, TEL 045-563-1141）
図 1 に, 東京・渋谷 Bunkamura で 2014 年に公開された, アーティスト永井秀幸氏による作品例のスナップショット を示す．彼による作品の多くは共通して，特定の視点から 観察した際，立てかけたスケッチブックの画用紙に続けて 描かれた絵が，紙面から飛び出しているように見える。こ れらの作品は, 制作時から特定の位置に視点（単眼）を固 定して描画を行う。その際，対象が滑らかにつながるよう に画用紙ごとに表示刘象を変形し，陰影付けを施している ため，折れ目が然程目立たなければ，L字状に置かれた画 用紙が形作る 3 次元空間内に，あたかも対象が存在するか のように，見る者は錯覚するのである.

このような描画原理は, アナモルフォーシスとよばれ，古 くはレオナルド・ダ・ヴィンチの時代から利用されてきた.

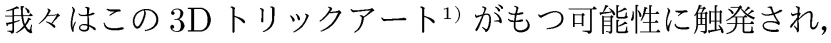
スケッチブックを 2 枚の狭額ディスプレイに置き換え，さ らに汎用ウェブカメラを利用して非接触に検知したユーザ 視線の情報を獲得し，上記の変形と陰影付けをリアルタイ ムに調整すれば，運動視差による増強効果も加わり，効果 的な裸眼立体表示機能を有する，個人向け環境を手軽に構 築できるのではないかという基本アイディアを着想した。

\section{2. 関 連 研 究}

立体映像を提示するうえで，本研究と同様にディスプレ イ，スクリーンを複数枚用いたシステムが数多く発表されて きた。代表的なものに, $\mathrm{CAVE}^{2)}$ に端を発する多画面没入 型のシステムがある. CAVE は複数の大型スクリーンを, ユーザを取り囲むように互いに直交に配置する。そして， 各スクリーンに背面投影された立体映像に全身が没入する 


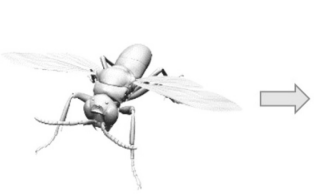

(a) 3D モデル入カ

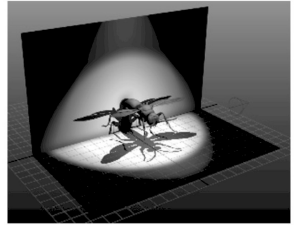

(b) 陰影付け

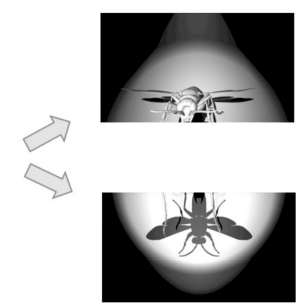

(c) off-axis 法による投影 (d) ユーザの顔追跡
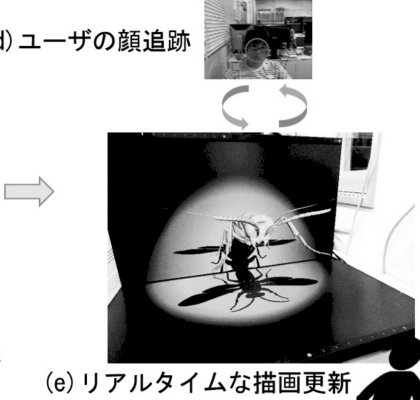

図 2 提案手法による処理の流れ

ような体験をユーザは得ることができる．このとき，投影 像とユーザが装着したアクティブシャッタ式メガネを同期 させることで両眼視差を与えている. Ueda ら（2014）に よる HaptoMIRAGE ${ }^{3)}$ は, モーションキャプチャによって ユーザ頭部位置の計測を非接触に行い, 三つのディスプレ イを介して裸眼でかつ複数人に対応可能な立体映像を実現 するが，表示装置が液晶ディスプレイ，アクティブシャッ タ, フレネルレンズの 3 層からなり, 手軽とはいい難い.

これらのシステムはいずれも, 両眼視差という生理的な 知覚要因を主要な奥行き手がかりに据えており, 表示装置 そのものを大幅に拡張, 高度化させている. 本研究では典 型的なラスタディスプレイの効果的利用を再考する. そし て, 表示ハードウェアの限界を打破するために, 視覚情報 を知覚する側, つまりヒトの視覚系における特徵的な挙動 である錯視現象という, 心理的要因による奥行き手がかり に着目する。

CAVE と本手法によるシステムはどちらも, アナモル フォーシス原理に基づき，ユーザ視点に応じて適切に投影 変換した映像を多画面上に表示する.ここで, 両者の目的 を改めて考えてみる. CAVE はユーザを取り巻くバーチャ ル空間を立方体に近似するという主旨をもつ。そのため, スクリーン間の境界は障害となるはずである. 実際, 小木 (1999） ${ }^{4)}$ は, CAVE 型システムのスクリーン境界付近に おいて, ユーザが知覚する奥行き情報の誤差が, スクリー ン平面と比較して増加すると報告している. 一方, 提案シ ステムでは 3 次元空間全域の均質的な表示が目的ではなく, 直交した複数のディスプレイが形成する L 字形状をなす表 示空間内に入力されたオブジェクトを, 中心的な立体視刘 象としている. 物理的に広視野な表示領域をユーザに提供 する目的で, スクリーンやディスプレイを複数枚利用して いる既存システム ${ }^{23)}$ では, 欠点となっているディスプレイ 境界を, 本手法ではむしろ積極的に利用し, ユーザに 2 枚 のディスプレイが壁と床の役割を担っていると意識させる.

この前提にたち, アナモルフォーシスの原理にしたがい, ユーザ視点から見て 2 ディスプレイ間の表示を滑らかにつ なぎ，オブジェクトが床と壁に落とす影を主な手がかりと した, 観察対象に対するユーザの奥行き知覚がより増強さ れる描画のアプローチが本研究の新規性である.

\section{3. 手 法}

図 2 に提案手法における処理の基本的な流れを示す。バー チャル空間に立体視刘象となるポリゴンモデル（図 2(a)） と，用いるディスプレイの大きさおよび位置に合わせた，壁 と床になぞらえた平面（それぞれ壁面，床面とよぶ）を入 力する.この際, 図 2(b) のように, 入力モデルを壁面と 床面が形作る L 字型空間の中心部に収まるよう配置する. そして, 二つのスポットライトを相異なる座標に配置し, 壁面と床面, および入力モデル上に陰影を生成する. 次に, 直交配置された各ディスプレイヘバーチャル空間を投影し (図 2(c)), ウェブカメラを用いたユーザの顔追跡によって バーチャルカメラ座標を制御し, 表示をリアルタイムに更 新する（図 2(d), (e)). 以下, それぞれの処理について詳 しく述べる.

\section{1 陰影の生成}

永井秀幸氏オリジナルのトリックアート (図 1)に見られ る, ある物体（図 1 における腕）が光路を遮って他の物体 (壁と床) に落とす影はキャストシャドウとよばれ，ヒトが 知覚する複数物体間の相刘的な位置関係を示唆する.図 $\mathbf{3}$ ではキャラクタは同じ高さにあるものの, キャストシャド ウの描画位置によって地面からの高さが異なって認識され ることが見てとれる. 提案システムがもつ L 字型表示領域 では, キャストシャドウは対象物体の床面からの高さを提 示する.つまり, 壁面ディスプレイの手前方向へユーザ視 線を誘導させることが可能であると期待できる.

そこで，次のように光源を配置する. 入力された $3 \mathrm{D} モ$ デルにおける, 最もバーチャルカメラに近い先端部分の座 標に刘して，その鉛直方向および斜め 45 度上方向に，ス ポットライトを配置する（図 2(b))。このとき, 対象モデ ルが照射範囲に完全に包み込まれるように, ビーム角を調 節する。

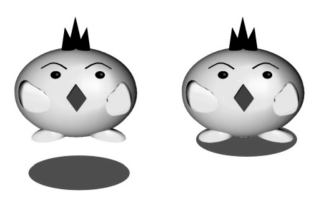

図 3 キャストシャドウの効果

映像情報メディア学会誌 Vol. 73, No. 1 (2019) 


\section{2 ディスプレイへの映像投影}

ビューポートへの投影面を壁面と床面にそれぞれ固定し た，同一座標をもつ 2 台のバーチャルカメラを用いて，offaxis 法による投影を行うことで，バーチャル空間をそれぞ れのディスプレイに描画する。これにより, 壁面および床面 の描画は変化せず $3 \mathrm{D}$ モデルのみが射影変換され (図 $2(\mathrm{c})$ ), バーチャルカメラ座標と刘応する実空間座標を観察視点と したアナモルフォーシス画像が得られる.

\section{3 顔追跡}

しかし，このままではこの効果をもつユーザ視点は，才 リジナルのトリックアートと同様に固定されたままである. そこで, 壁面ディスプレイ上部に取り付けたウェブカメラ によりユーザの顔をリアルタイムに追跡し，ユーザ頭部と バーチャルカメラの位置を同期させる．本システムでは, 正 確でありながら高速に対象物体を検出できる Viola-Jones 法5)を適用し, ユーザの顔追跡を行っている. ウェブカメ ラで得られた画像内からユーザの顔を検出すると, 顔と推 定される範囲を円で近似し（図 $2(\mathrm{~d})$ ), その中心座標と直 径を用いることで, バーチャルカメラの 3 次元位置を制御 している.

また, 聴覚によって視覚効果を補助するため, バーチャ ルスピーカを入力モデル位置に, バーチャルリスナをバー チャルカメラ位置にそれぞれ配置し, システムとユーザの 相対位置に応じて, 音源（図 2(a) の入力モデルでは羽音） の音量と音高を変化させている.

\section{4. 結果と評価}

開発環境として PC (CPU: Intel Core i7-4770K, GPU: NVIDIA GeForce GTX 650Ti, 実装メモリ : 8GB), ウェ ブカメラ : Logicool Webcam C270, C910, ディスプレィ: EIZO FlexScan EV2450 を用い, プログラミング言語に Delphi, 顔追跡のための API として OpenCV2.36) を用い た. また, 一部シーンのレンダリングに $3 \mathrm{DCG}$ ソフトウェ ア7)を用いている.

この環境のもと, 提案手法によって生成した映像例を図 4 に示す。それぞれ左から順に，ユーザが顔を近づけてい きながら視点を変更した結果例である，実際に視点を移動 させたときの感覚に近い効果を, 添付動画で確認されたい.

\section{1 評 価}

本手法による立体視の効果を検証するため, 上述の実装 環境において, ユーザ評価を行った. 複数のディスプレイ 間でユーザ視線がどのような挙動を示すか確認するため, 予備実験として, あらかじめ L 字型表示面による提示映像 をビデオ撮影しておき，その撮影映像に対してユーザ視線 の追跡を行った。同一の $3 \mathrm{D}$ モデルを入力とし, 提案手法 によるシーン, 光源として環境光のみを使用し, キャスト シャドウが生成されないシーン（以下，影なしとする）お よび床と壁の構図をもたないシーン（以下，自由曲面とす る）という 3 種類のシーンを, 視力（矯正視力含む） 1.0 以
表 1 描画方法に対する立体感の比較結果（実験参加者数：6）

\begin{tabular}{|l|c|c|c|}
\hline & 提案手法 & 影なし & 自由曲面 \\
\hline 平均得点 & 2.67 & 2.33 & 1.50 \\
\hline
\end{tabular}

上の正常な視覚をもつ 6 人の実験参加者（男性 5 人，女性 1 人)を対象に 15 秒間提示し, 自由に観察するよう指示し た。視線追跡装置は Tobii X2-60 Eye Tracker1 台を使用 し, PC (CPU: Intel Core i7-5600U, 実装メモリ : 16GB) にて制御した。

図 5 に, 3 種類の提示映像と 1 人の実験参加者による注 視点の軌跡（橙色の円が注視点を表し，それを繋ぐ線分が その軌跡を示す）の重畳画像を示す．左から順に提案手法， 影なし, 自由曲面による提示画像である. ビデオ撮影時, シーンの種類以外の条件が揃うよう, 撮影機器の位置や画 角等が同一となるよう注意を払った。

図 5 から，提案手法によるシーンでは $3 \mathrm{D}$ モデル（バッ タ）伝いにユーザ視線が移動しているが, 影なしの場合, ディスプレイ境界付近で停留が発生していることが見てと れる.さらに, 自由曲面の場合, 視線が散乱しており, $3 \mathrm{D}$ モデルに注目しているとはいえない．他の実験参加者にお いても，同様な視線軌道をとる傾向が確認された。

さらに上記の実験参加者に, 得られた立体感を 3 段階で得 点付けさせ, 定性的な評価を行った。実験参加者に, (1) 3D モデルが壁面ディスプレイ手前に飛び出しているように感 じた，(2)やや感じた，(3) 感じなかった，という 3 種類の 評価項目から一つを選択させ，それぞれ $3 ， 2 ， 1$ の得点を もたせた．各シーンに対する平均得点を表 1 に示す。この 結果から, 提案手法によるシーンに含まれる壁と床の構図 およびキャストシャドウが，表示対象に対するユーザの立 体感の向上に寄与していることがわかった。

以上から, 提案手法によるシーンは, ユーザを入力モデ ルに注目させ，壁面ディスプレイの手前方向に視線を誘導 していると考えられる.

\section{5. 拡 張}

CAVE 型システムの問題として, 装置自体が実環境から 隔離され，プロジェクタを用いるため暗室が前提となるの で，外部環境のセンシングが難しい. 装着デバイスも必要 なこともあり，ユーザは知覚する対象が現実ではないバー チャル空間であると, 暗黙のうちに了解してしまっていて, 無意識に身構えてしまう。本研究における錯視を引き起こ すには, システムと現実世界との親和性が重要であると考 えた。そこで，現実世界の情報を採り入れることで，バー チャル空間を際立たせる Augmented Virtualty の概念を システム周辺環境のセンシングが可能な本手法に採り入れ, 以下に示すような観察対象を際立たせる強調表示を施した。

永井秀幸氏の作品では, 図 6 左のように紙面を切り取り, 実世界を背景にすることでより立体感を強調している例が 

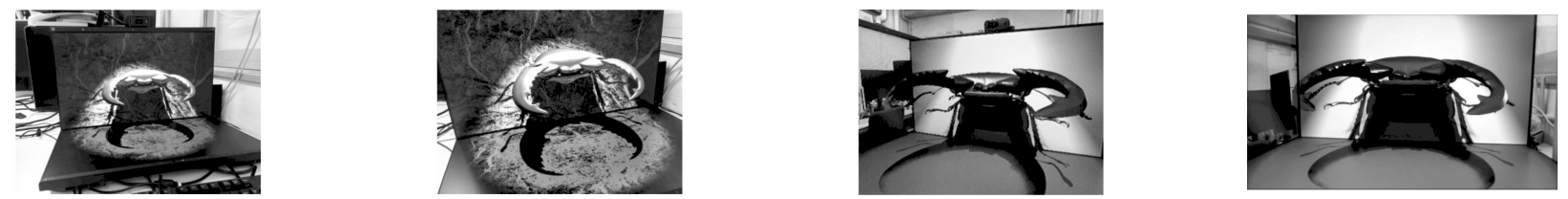

図 4 本手法による映像の生成例 (動画). 右側 2 例は 5 節におけるディスプレイ 3 枚を用いた例である. それぞれ 左から，ユーザの視点位置に応じた遠景，近景を示す．動画は電子付録として閲覧可能である.
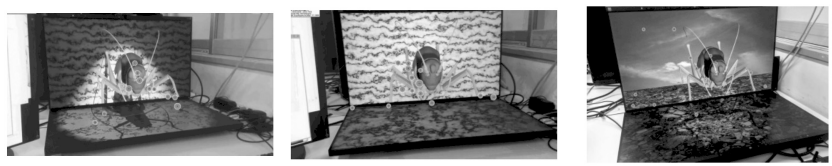

図 5 提示シーンとユーザ注視点の重畳画像. 左から提案手法 によるシーン，影なし，自由曲面である．

ある.この例にならって, ディスプレイとウェブカメラを システムに 1 台ずつ追加し, 前者を既設ディスプレイと直 交に，後者を新設ディスプレイの背面方向をキャプチャす るように配置する，実背景との差異を削減するため, 3.3 項 の顔追跡結果を利用し，キャプチャ画像をデバイス座標系 からユーザ視点座標系へと変換する.

このウェブカメラから得られた動画像を壁面のテクスチャ 画像の代わりに用いることで, ユーザがシステムの横へ回 り込むと途切れるはずであった表示刘象が完全に表示され, 壁面から $3 \mathrm{D}$ モデルが実環境に飛び出ているような効果を 生むことができる（図 4 右側 2 例). 背景がキャプチャ動 画であるため, 外部環境の変化がリアルタイムで反映され る.ウェブカメラから取得した実環境画像を図 6 右のよう にキューブマッピング用のテクスチャとして利用すること で, システム周囲の実環境の映り込みを疑似的に再現した。 3D モデル表面への映り込みがユーザ視点に応じて変化す るので，運動視差を増強することができる.
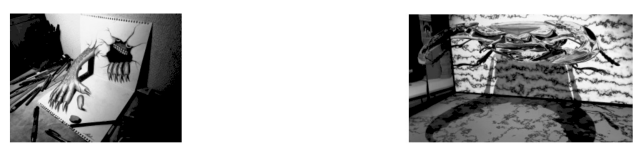

図 6 Augumented Virtualty の概念に基づくシステムの拡 張. 左が紙面を切り取り立体感を強調している永井秀幸 氏の作品例. 右が 3 面のディスプレイ用い, かつモデル テクスチャにキューブマッピングを施している例（動画） である.

\section{6. むす び}

本論文では，ディスプレイの物理的な構成と，陰影を中 心とした心理的な奥行き知覚を組み合わせることで, 汎用 デバイス上で品質（解像度, 明度）を損なうことなく, 表

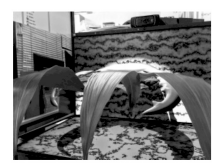

図 7 床面ディスプレイの手前に遮蔽物（葉）を配置した例 (動画).

示対象を裸眼立体視するための手法を提案した. 4.1 項に おける評価結果から, 本研究の目標は達成できたと考える. 本手法によるシーンは, 単眼で観察すると立体感が増強 される特徴をもつ. 図 7 にディスプレイ上の単眼視領域を 拡大する目的で，システム前方に遮蔽物を配置した例を示 す。こうすることで，ユーザに片目を瞑らせたりすること なく，前述した特性の利用が可能である．今後はこのよう に, 両眼視差に頼らずとも立体感を増強可能な方策を追究 する予定である．本システムは，L字型の構造が多く含ま れる人工物に埋め込みやすい形状であり, 現代社会の中で 活きるシステムであると考えている。

作品画像の掲載許可をいただいた永井秀幸氏に謝意を表 する. 視線追跡による評価についてお力添えいただいた山 梨大学大学院総合研究部の茅暁陽教授に感謝する.また, 検証実験に協力していただいた参加者の皆様にお礼申し上 げる. 本研究の一部は, 日本学術振興会科研費挑戦的萌芽 領域 15K12034 の支援を受けて実施したものである.

\section{〔文献〕}

1）永井秀幸 : 錯覚体験!! 3D トリックアート, 汐文社 (2014)

2) C. Neira, D. Sandin, and T. DeFanti: "Surround-screen projection-based virtual reality: The design and implementation of the CAVE," Proceedings of the 20th Annual Conference on Computer Graphics and Interactive Techniques, pp. 135-142 (1993)

3) Y. Ueda, K. Iwazaki, M. Shibasaki, Y. Mizushina, M. Furukawa, H. Nii, K. Minamizawa, and S. Tachi: "HaptoMIRAGE: Midair autostereoscopic display for seamless interaction with mixed reality environments," Proceedings of ACM SIGGRAPH 2014 Emerging Technologies, 10 (2014)

4) T. Ogi: "Characteristics of immersive projection displays and their applications," The Transactions of Human Interface Society, 1, pp. 43-49 (1999)

5) P. Viola and M. Jones: "Robust real-time facedetection," International Journal of Computer Vision, 57, 2, pp. 137-154 (2004)

6) OpenCV2.3, http://sourceforge.net/projects/opencvlibrary/files/ opencv-win/2.3.1/（最終アクセス日：Jan. 10, 2016）

7) Autodesk Maya, http://www.autodesk.co.jp/products/maya/ overview/（最終アクセス日：Jan. 10，2016）
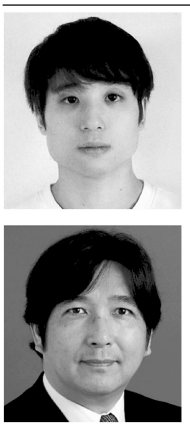

宑阪 茟 2014 年, 慶應義塾大学理工学部情報 工学科卒業. 2016 年, 同大学大学院理工学研究科開放 環境科学専攻修士号取得. 同年, 日本電信電話（株）入 社. 現在, 同社 NTT サービスエボリューション研究所 所属. 立体映像の研究に従事.

藤代 いっせい 学研究科電子・情報工学専攻修士号取得退学. 1988 年, 理学博士 (東京大学). 東京大学助手, 筑波大学助手・講 師, お茶の水女子大学助教授・教授, 東北大学教授を経 て，2009 年より慶應義塾大学理工学部情報工学科教授, 現在に至る. ビジュアルコンピューティング全般の研究 に従事. 正会員. 